\title{
Using Authentic Assessment to Better Facilitate Teaching and Learning: \\ The Case for Students' Writing Assessment
}

\author{
Elva Moria, Refnaldi, and M. Zaim \\ English Language Education \\ Universitas Negeri Padang \\ elvamoria77@gmail.com, refnaldi@yahoo.com, mzaim_unp@yahoo.com
}

\begin{abstract}
The issues on the use of authentic assessments have been arising over the time. Various forms of assessment had been employed in the teaching and learning activities. Among of them, authentic assessment has been considered as an appropriate assessment to be used in education since it has various forms of assessment and its purpose is to create a meaningful learning. This assessment can be useful for assessing productive skills in language learning. A model of authentic assessment suitable for assessing writing skill, one of the productive language skills, had been developed by the writers. This article investigates the implementation of the authentic assessment model in classrooms practice. It specifically examines the use of authentic assessment to enhance students' learning and creativity for writing skill. Two English teachers were observed while implementing the authentic assessment model. 124 students were asked to give their perception of the implementation of the authentic assessment model. The result shows that authentic assessment is effective to encourage students' interest and critical thinking in writing. The students were exited in finishing any kind of the assignments. The authentic assessment allows the teachers to evaluate students' skills in writing intensely. It can be concluded that authentic assessment can be used to better facilitate teaching and learning, especially for writing ability.
\end{abstract}

\section{Keywords- Authentic Assessment, Writing Skill, Teaching English, Writing Assessment}

\section{INTRODUCTION}

Assessment is central to teaching and learning (Bordoh et al., 2015). It is a process to gather information about students' learning process. The information is needed to make decisions regarding students' learning abilities, their placement in appropriate levels or groups and their achievement (Kankam, 2015). Assessment serves as assistance for teachers in deploying the students into certain groups, improving teaching method and providing guidance (Retnawati, Hadi, and Nugraha, 2013). Through assessment, teachers can determine students' success in learning. Assessment can be a reflection of teachers' success in teaching. Assessment is a crucial thing that should be paid attention in teaching and learning process since it can be a tool or a measurement to see the success of teaching and learning process.

Nowadays, the use of authentic assessment in teaching and learning process becomes popular (Aitken and Pungur, 2005). Since there is a need for more holistic approaches for evaluating students. Traditional assessment fails to assess an overall ability of students because it focuses on knowledge rather than skill (Zaim \& Refnaldi, 2016). Authentic assessment occurs within the context of an authentic activity with complex challenges and centers on an active learner that produces refined results or products and is associated with multiple learning indicators (Herrington and Herrington, 2006). This kind of assessment assesses students' performance in the real-life context. Keyser and Howell (2008) state that authentic assessment mirrored real-world tasks rather than a contrived learning experience of the classroom-based worksheet or test. Moreover, Stiggin (1987), Schurr (2002), Zaim (2013), and Gulliker er al (2014) state that authentic assessment is the way of a teacher to evaluate students' knowledge that is realistic and relevant and applicable for them in real-life experience. Authentic assessment is multiple forms of assessment that is consistent with the classroom goals, curriculum, and instruction and reflect students learning process, achievements, motivation, and attitude (O'Malley and Pierce, 1996; Callison, 1998; Olfos and Zulianty, 2007). Authentic assessment is a process of engaging worthy problems or important questions in which students have to use knowledge to fashion performances effectively and creatively. The authentic assessment evaluates not only the products but also the process involved (Wiggin, 1993; Olfos and Zulantany, 2007; Zaim, 2013).

Teaching English in junior high school is expected to enable students to reach the level of function in which students are competent at oral and written communication in English to cope with daily needs. Thus, teachers need to improve their assessment system. Koh (2015) argue that in competency-based curriculum and outcome-based learning, building teachers' capacity in implementing authentic assessment is one of the key priorities in in-service teacher education and professional development. Therefore, authentic assessment should be used by teachers in teaching and learning process to achieve the competency needed (Guliker et al., 2014; Zaim and Refnaldi, 2016).

There are some characteristics of authentic assessment. It (1) requires students to perform, create, produce or do something, (2) uses real world context or simulations, (3) is non-intrusive in that it extended the day do day classroom activity, 
(4) allows students to be assessed on what they usually do in class every day, (5) uses a task that represent meaningful instructional activities, (6) focuses on process as well as product, (7) taps into higher level thinking and problem solving skill, and (8) provides information about strengths and weakness of students (Brown, 2004). Thus, authentic assessment can be one solution for assessing learning activities. In addition, Imran (2012) mentions that an authentic assessment is intended for measuring knowledge and skills of the students, assessing students' performance with relevant and contextual tasks and various ways and form of sources.

Brown and Abeywickrama (2010) propose six types of authentic assessment that can be used in assessing language skills. They are performance-based assessment, portfolios, journal, conferences and interview, observation, self, and peer-assessment. Brown called them an alternative assessment. Those assessments can be used to assess students' language ability in specific language skills such as reading, writing, speaking and listening. A teacher can select types of authentic assessment based on the need to assess which kind of competency (O'Malley and Pierce, 1996).

Some researchers have proved the effectiveness of using authentic assessment in teaching and learning process. McCarthy (2013) found that authentic assessment can engage millennial students in the learning process. The finding shows that not only having analytical and evaluation skill, but also self-assessment and self-reflection skills that ensure students graduate as reflective practitioners and equipped for continuing professional development. In other words, authentic assessment encourages students to be ready to live in the real world situation. Then, Nezakatgoo (2011) reveals that students whose work was evaluated by a portfolio had improved in their writing and gained higher scores in the final examination compared with those who were assessed by the traditional evaluation. The finding of this study highlighted the fact that portfolio assessment can be used as an alternative assessment along with traditional assessment on the process of teaching writing skill. Carrion (2012) found that authentic assessment was the type of assessment that enhanced students' performance the most, as it is authentic and mirrors students' real professional contexts.

The studies above proof the increasing of the use of authentic assessment in learning. The writers found some advantages of using authentic assessment. However, there is no study investigating the need for authentic assessment at school. An authentic assessment should be well developed and implemented to better-facilitated the teaching and learning process. This article tried to investigate the implementation of the authentic assessment model and the perception of teachers and students related to the application of the authentic assessment model.

The development of an authentic assessment needs a long process. The process begins with a need analysis by considering the curriculum and school environment. The result of need analysis is used to design a model of authentic assessment and develop a model of authentic assessment that is suitable for the need of the teachers. Then, it is implemented and evaluation to know the effect on the model developed. The writer uses ADDIE model in developing the model of authentic assessment of writing. According to this model, there are five steps in developing a model of instruction: analysis, design, development, implementation, and evaluation. The authentic assessment model that will be implemented should be validated by assessment expert before it is used by the teachers in teaching and learning process.

\section{METHOD}

The data of this research were collected by observing two English teachers in implementing the authentic assessment model of writing. The two English teachers taught at grade VIII Junior High School. Teacher A taught at class VIII.1 and VIII.2, while teacher B taught at class VIII.3 and VIII.4. These classes are homogenous. The data about the implementation of the authentic assessment model were gathered through observation, and the data about the students' perception were gathered to 124 students through questionnaire. Five types of authentic assessment were implemented by the two teachers; they are writing prompts, project/exhibition, picture description, journal, and process writing. Teachers' and students' perceptions were asked to know their point of view about the authentic assessment model given.

\section{FINDING AND DISCUSSION}

Five types of authentic assessment for writing skills had been implemented by two English teachers in four classes of grade VIII students of Junior High School. The findings can be shown as follows.

\section{The Implementation of Authentic Assessment Model of Writing Skill}

The first assessment that was implemented by the teachers was writing prompts. Before administering the assessment, the teachers gave an explanation about the assessment system. In this assessment, the students were asked to write short message based on the prompts given. There were five prompts provided in the assignment form. 30 minutes were provided for the students to finish the assignment. The students seem interesting since the prompts were short and easy to be understood. They can complete doing the task in the time given.

The second type of assessment was project/exhibition. This assessment needs students' creativity in producing a piece of written work. The students were asked to create some kinds of project related to several language functions such as short message, notice, advertisement, and descriptive. The focus of this assessment was about students' creativity in creating a written 
product. Teachers asked the students to write an invitation. The results of the students' works reflect their effort in creating an exciting product.

The third assessment was picture description. Several pictures were provided in this assessment. The students were free to choose one of the pictures they want to describe. The students were asked to describe the picture. They have 30 minutes to describe it. The students look very excited about doing this assignment, but some of them could not finish it on the time given.

The fourth assessment was journal. There were two kinds of journal that the students were asked to do. They are daily journal and reading journal. The two teachers chose to implement reading journal assignment. The template had been provided by the teacher. In this assignment, the students were asked to report what book they had read today, how much time they spend to read in that day and several new words they found in their reading. In addition, they were asked to list some evens happened today. The teachers did not focus much on the grammar but the effort of the students to read and write.

The last assessment was process writing. This assessment requires the teachers to assess the process instead of product. Teachers were asked to collect all of the drafts of students' writing and asked to analyze the progress of each draft. There were three steps that have to be completed by the students; pre-writing, writing, and post-writing. Some students seem confuses to think about the topic and title they want to write. However, the template could guide them to write easily. The students' writings were collected by the teachers. Teachers were required to assess the process and progress of students writing instead of the final written product.

After the teachers implemented the four types of authentic assessment, the average scores of the students' works were calculated. The score recapitulation can be seen in the table 1:

TABLE 1: STUDENTS' AVERAGE SCORES ON FIVE TYPES OF AUTHENTIC ASSESSME
\begin{tabular}{|l|l|c|}
\hline No & Types of Authentic Assessment & $\begin{array}{c}\text { Students' Average } \\
\text { Score }\end{array}$ \\
\hline 1 & Writing Prompts & 80,56 \\
\hline 2 & Journal & 79,38 \\
\hline 3 & Project/exhibition & 78,39 \\
\hline 4 & Process Writing & 75,83 \\
\hline 5 & Picture Description & 74,44 \\
\hline & Total score & $\mathbf{3 8 8 , 6}$ \\
\hline & Average Score & $\mathbf{7 7 , 7 2}$ \\
\hline
\end{tabular}

The table 1 above shows that the highest average score was on writing prompts $(80,56)$, and the lowest score was picture description $(74,44)$. The average score for all types of authentic assessment was 77,72. Two types of authentic assessment were still below the average score; they are process writing and picture description. However, students' average score for all assignment was higher than minimum criteria score at this school (73). It can be implied that authentic assessment model that was developed can be used facilitate teaching and learning English, especially for writing skill.

This finding is in line with Ann (2015) who found that authentic assessment provided students for values internalization. Authentic assessment is not only used at secondary school, but it is also highly used in college. Ann (2015) said that the use of authentic assessment could clarify someone's thinking, prepare the students for discussion, and can be used to apply the elements of effective writing. Authentic assessment has advantages for students and teachers. For students, with the authentic assessment, their true abilities can be well measured. For teachers, various forms of authentic assessment are expected to facilitate measuring exact students' language abilities and skills (Taufina, 2009; Zaim \& Refnaldi, 2016).

\section{Teachers' and Students' Perception of the Authentic Assessment Model}

Teachers' and students' perceptions about the authentic assessment model were asked. To see their point of view about the authentic assessment model which was done through questionnaire. Seven questions were asked to the students, (1) the level of easiness of the assessment, (2) the interest of the assessment, (3) language use in the assessment, (4) the usefulness of the assessment, (5) the practicality of the assessment, (6) the media used, and (7) the time provided in doing the assessment. The finding can be seen in the table 2 .

TABLE 2: STUDENTS' PERCEPTION OF THE DEVELOPED AUTHENTIC ASSESSMENT
\begin{tabular}{|l|l|c|c|}
\hline No & \multicolumn{1}{|c|}{ Students' perception point } & Score & Classification \\
\hline 1 & The level of easiness of the assessment & 2,9 & Easy \\
\hline 2 & The interest of the assessment & 3,4 & Interesting \\
\hline 3 & Language use in the assessment & 3,4 & $\begin{array}{c}\text { Easy to be } \\
\text { understood }\end{array}$ \\
\hline 4 & The usefulness of the assessment & 3,4 & Useful \\
\hline
\end{tabular}




\begin{tabular}{|l|l|c|c|}
\hline TABLE 2: CONT \\
\hline 5 & $\begin{array}{l}\text { The practicality of the assessment and } \\
\text { students' learning interest }\end{array}$ & 3,5 & $\begin{array}{c}\text { Increase students' } \\
\text { interest }\end{array}$ \\
\hline 6 & The media used in the developed model & 3,3 & $\begin{array}{c}\text { Clear and } \\
\text { interesting }\end{array}$ \\
\hline 7 & The time & 2,1 & Enough \\
\hline & Total Score & $\mathbf{2 2}$ & \\
\hline & Average Score & $\mathbf{3 , 1 4}$ & \\
\hline
\end{tabular}

The table 2 shows that the students' perception of the authentic assessment model that had been implemented by the teachers is good. It shows that six points gained high score. They are the easiness $(2,9)$, interest of the assessment $(3,4)$, language use in the assessment $(3,4)$, the usefulness of the assessment $(3,4)$, the practicality of the assessment and students' learning interest $(3,5)$, and the media used in the assessment $(3,3)$. However, the time provided for the students for finishing the assessment got the lowest score $(2,1)$. It indicates that some students need more time to finish the assignments. These findings show that the authentic assessment model is easy, useful, clear, interesting, and can increase students' interest in writing.

Related to the result of this research, Nurgiyantoro and Suyata (2009) stated school teachers expect the guidebook for implementing authentic assessment to measure language proficiency, easy to follow and contains examples of the assessment. The model of authentic assessment can fulfill this requirement. Moreover, Kankam (2015) stated senior high school teachers need regular training and capacity building workshop on authentic assessment to improve their use of authentic assessment as a tool to enhance teaching and learning. To implement authentic assessment well, we should have a model of authentic assessment suitable with teachers' need and teachers should be well prepared in performing the authentic assessment at school.

\section{CONCLUSION AND RECOMMENDATION}

Authentic assessment is adequate to encourage students' interest and critical thinking, especially in writing. This process allows the teachers to evaluate students in writing intensely. In addition, students were exited in finishing any kind of writing assignments that had been developed. Authentic assessment can be used to better facilitate teaching and learning of English, especially for writing.

\section{References}

Aitken, N., and Pungur, L. (2005). Authentic Assessment: Literature Synopsis. Retrieved on July 2016 from http://www.ntu.edu.vn/Portals/96/.../authentic assessment.

Ann, R. (2015).International Journal of Education and Social Science. A Survey of Authentic Assessment in Teaching of Social Sciences. Vol 2 No. 6

Bordoh, A., Eshun, I., Quarshie, M., Bassaw, T.K., and Kwarteng, P. (2015). Social Studies Teachers' Knowledge Base in Authentic Assessment in Selected Senior High Schools in the Central Region of Ghana. Journal of Social Science and Humanities, 1 (3) 249-257.

Brown, H. D. (2004). Language Assessment Principles and Classroom Practices (Second Edition). New York: Pearson Education, Inc.

Brown, H, D., and Abeywickrama, P. (2010). Language Assessment Principles and Classroom Practices (Second Edition). New York: Pearson Education, Inc

Callison, D. (1998). Authentic Assessment. Journal School Library Media Activities Monthly. Bloomington: Indiana University

Gulikers, J., Bastiaens, T.M, Theo J. and Kirschner, P.A. (2014). Perception of Authentic Assessment: Five Dimension of Authenticity. Educational Technology Research and Development.

Herrington, J. A. \& Herrington, A. J. (2006). Authentic conditions for authentic assessment: aligning task and assessment. In A.Bunker \& I. Vardi (Eds.), Proceedings of the 2006 Annual International Conference of the Higher Education Research and Development Society of Australasia Inc (HERDSA): Critical Visions: Thinking, Learning and Researching in Higher Education: Research and Development in Higher Education, Volume 29 (pp. 141-151). Milperra, NSW: HERDSA.

Imran, S. (2012). Authentic Assessment. http://ipankreview.wordpress.com/. Retrieved on July 2015.

Kankam, B (2015). Teachers' Perception of Authentic Assessment Techniques Practice in Social Studies Lesson in Senior High Schools in Ghana. Ghana: International Journal of Educational Research and Information Science.

Keyser, S and Howel, S.L. (2008). The State of Authentic Assessment. Brigham: Young University.

Koh, Kim (2015). Building Teachers' Capacity in Authentic Assessment and Assessment for Learning. Proceeding of the IDEAS. Calgary: University of Calgary:

McCarty, G. (2013). Authentic Assessment - Key to Learning. Wollongong: University of Wollongong, Faculty of BusinessPapers 
Nezakatgoo, B. (2011). The Effect of Portfolio Assessment on Writing of EFL Students. Iran. Retrieved on January 2017.

Nurgiantoro, B. dan Suyata, P. (2009). Pengembangan Model Asesmen Otentik Dalam Pembelajaran Bahasa. Cakrawala Pendidikan, November 2009, Tahun XXVIII, No. 3:224-237

Olfos, R. and Zulantay, H. (2007). Reliability and Validity of Authentic Assessment in a Web-Based Course. International Forum of Educational Technology and Society.

O’Malley, J.M. and Pierce, L.V. (1996). Authentic Assessment for English Language Learners: Practical Approaches for Teacher. New York: Addison-Wesley Publishing Company.

Retnawati, Hadi, and Nugraha (2016). Vocational High School Teachers' Difficulties in Implementing the Assessment in Curriculum 2013 in Yogyakarta Province Indonesia. International Journal of Instruction.

Schurr, L.S. (2002). Authentic Assessment: Professional Reference for Teacher. Journal Teaching at Middle School.

Stiggin, R.J. (1987). Revitalizing Classroom Assessment: The Highest Instruction Priority. Phi Delta Kappa.

Taufina. (2009). Authentic Assessment dalam Pembelajaran Bahasa Indonesia di Kelas Rendah SD. PEDAGOGI: Jurnal Ilmiah Ilmu Pendidikan. Volume IX No.1 April 2009 (113-120).

Zaim, M. (2013). Assessment Otentik: Implementasi dan Permasalahannya dalam Pembelajaran Bahasa Inggris di Sekolah Menengah. Proceeding of the International Seminar on Languages and Arts. (39-61) Padang: FBS UNP Press.

Zaim, M. and Refnaldi (2016). Teachers' Need on Authentic Assessment of Speaking Skills, Proceeding of the International Seminar on Languages and Arts 5. Padang: FBS UNP Press. 